\title{
Characteristics and outcomes of patients with COVID-19 and liver injury: a retrospective analysis and a multicenter experience
}

\author{
ANDREI VOIOSU ${ }^{1,3}$, ADINA ROMAN ${ }^{4,5}$, RUXANDRA POP ${ }^{1}$, ALINA BOERIU $^{4,5}$, CRISTIANA POPP $^{2,3}$, \\ SABINA ZURAC ${ }^{2,3}$, THEODOR VOIOSU ${ }^{1,3}$, DANIELA DOBRU $^{4,5}$, BOGDAN MATEESCU $^{1,3}$
}

\author{
${ }^{1}$ Gastroenterology Department, Colentina Clinical Hospital, Bucharest, Romania \\ ${ }^{2}$ Pathology Department, Colentina Clinical Hospital, Bucharest, Romania \\ ${ }^{3}$ Carol Davila University of Medicine and Pharmacy, Bucharest, Romania \\ ${ }^{4}$ Gastroenterology Department, Mureș County Clinical Hospital, Romania \\ ${ }^{5}$ University of Medicine, Pharmacy Sciences and Technology “George Emil Palade” Târgu Mureș, Romania
}

\begin{abstract}
Background and aims. Patients with COVID-19 frequently present abnormal elevated liver function tests of unknown clinical significance. We aimed to investigate the characteristics and factors influencing outcome in patients with confirmed SARS-CoV-2 infection and liver injury on admission.

Methods. This is a retrospective observational study of patients hospitalized in two COVID units in Romania. Relevant data on clinical and laboratory parameters and medication administered during the admission were analyzed to identify predictors of a negative outcome. Patients with confirmed COVID-19 and liver function tests (LFTs) above the upper limit of normal were included in the analysis.

Results. From 1,207 patients, we identified 134 patients (11\%) with abnormal LFTs during hospitalization. The majority of patients had mildly elevated levels and a predominantly cholestatic pattern of liver injury. Patients who received lopinavir/ritonavir were more likely to have increased ALAT levels $(p<0.0001)$. Sixteen patients had pre-existing chronic liver disease, and they were more likely to suffer from severe COVID-19 ( $\mathrm{p}=0.009)$ and have a negative outcome $(\mathrm{p}<0.001)$, but on multivariate analysis, only the severity of COVID-19 was predictive of death (OR 69.9; 95\% CI 6.4-761.4).

Conclusions. Mild liver injury is relatively common in COVID-19 and possibly influenced by medication. Patients with chronic liver disease are at high risk for negative outcome, but the severity of the infection is the only predictor of death.
\end{abstract}

Key words: COVID-19, liver injury, SARS-CoV-2, drug-induced liver injury, hepatitis, hydroxychloroquine, lopinavir/ritonavir, antiviral therapy.

\section{What is new? What is important?}

Mild liver injury is relatively common in COVID-19 and possibly influenced by medication. Patients with chronic liver disease are at high risk for a negative outcome, but the severity of the infection is the only predictor of death.

\author{
Abbreviations: \\ COVID-19 - coronavirus disease 2019 \\ SARS-CoV-2 - severe acute respiratory disease coronavirus 2 \\ RT-PCR - real-time polymerase chain reaction \\ ALAT - alanine aminotransferase \\ ASAT - aspartate aminotransferase \\ GGT - gamma-glutamyl transpeptidase \\ LFT - liver function test \\ $\mathrm{Hb}$ - hemoglobin \\ WBC - white blood cell count \\ CRP - C-reactive protein \\ $\mathrm{Na}$ - sodium \\ $\mathrm{K}$ - potassium \\ ULN - upper limit of normal
}




\section{INTRODUCTION}

Coronavirus disease 2019 (COVID-19) is now known to induce complications beyond respiratory failure, and occurrences such as liver injury can affect a significant proportion of patients [1]. In order to help predict the outcome of COVID-19 in different patient groups, tremendous amounts of data have been collected, and rapid strides have been made in our understanding of the clinical relevance of pathological findings [2].

The distribution of the ACE2 receptor, identified as the viral entry point for SARSCoV2, is responsible for the systemic spread of COVID-19, which leads to cardiovascular, neurologic, muscular, pancreatic, and hepatic injury [3]. There are indirect data on permissive hepatic tropism for SARS-COV2, which favors a direct cytopathic effect, but a typical form of viral hepatitis has not been documented, and further study in this area is necessary [4].

Several recent studies report on the frequency of liver injury in cohorts of patients suffering from COVID-19 [5], and extensive online registries have been set up to accrue sufficient cases for sound analysis [6]. The datasets already published vary widely, but most of them show that slight abnormalities in liver function tests (LFTs) are pretty common and generally associated with the severity of COVID19 [7]. Mild transaminase elevations were associated with prognosis in some reports, but there is uncertainty regarding the hepatic source of these modifications, especially concerning aspartate aminotransferase (AST). Furthermore, while comorbidities are apparent risk factors for dismal outcome in severely infected patients, there is little data on the impact of SARS-CoV-2 in patients with pre-existing chronic liver disease [8]. We aimed to investigate the pattern of liver injury and its impact on outcome in patients admitted with COVID-19.

\section{MATERIAL AND METHODS}

We conducted a retrospective observational study of 1,207 patients with RT-PCRconfirmed SARS-CoV-2 infection admitted to 2 dedicated COVID units in Romania during a three month-period. We used the standard definitions of COVID-19 severity [5] and stratified patients into two groups: non-severe (mild/moderate forms) and severe (severe/critical forms). We collected electronic and paper health records, including medical history, drug use during admission, relevant laboratory results, and radiologic investigations.

For this study, we defined abnormal liver function tests as at least one value two times higher than the upper limit of normal for alanine aminotransferase (ALT) and/or aspartate aminotransferase, total bilirubin (TB), alkaline phosphatase (ALP), and/or gamma-glutamyl transferase (GGT). The upper limit of normal was as follows: ALT, $40 \mathrm{IU} / \mathrm{L}$; AST $40 \mathrm{IU} / \mathrm{L}$; TB, $1.2 \mathrm{mg} / \mathrm{dL} ;$ GGT $50 \mathrm{IU} / \mathrm{L}$ and ALP $125 \mathrm{IU} / \mathrm{L}$. We assessed the odds of progressing to severe disease in patients with abnormal liver tests of hepatocellular or mixed type. Preexisting chronic liver disease was recorded in order to classify patients.

In order to assess independent risk factors of the paraclinical characteristics and the demographics of the severity of COVID-19 in patients with abnormal LFTs, logistic regression analysis was performed after univariate and multivariate analysis.

Statistical analysis was performed using GraphPad Prism 9, and Fisher's exact test was applied for categorical variables. We used the Mann-Whitney U test for continuous variables, and the results were presented as the median (25\%-75\% interquartile range, IQR). A $p$-value $<0.05$ was considered statistically significant.

Standard written informed consent for this study was obtained together with the approval of the ethical committees of both centers.

\section{RESULTS}

\section{Demographics}

Out of 1,207 patients admitted, a total of 134 patients (11\%) met the inclusion criteria and are analyzed in this study. The cohort consisted of 69 women and 65 men with a mean age of $52 \pm 15$ years. $64.9 \%$ were symptomatic, while $22.4 \%$ were diagnosed with a severe form of COVID-19 based on clinical, biological, and radiological evidence. Patients with severe COVID-19 were more likely to be older, symptomatic, with a higher Charlson comorbidity index, prior liver disease, lower platelet and hemoglobin values, and higher C-reactive protein levels (Table 1). 
Table 1

Characteristics of the study population and comparison of main parameters according to the severity of the COVID-19 infection. Medians and IQRs are presented for continuous variables. Mann-Whitney U was used for continuous variables with non-normal distribution, $\mathrm{t}$-test for variables with normal distribution, and $\chi^{2}$ for categorical variables, with $\mathrm{p}<0.05$ considered statistically significant. $\mathrm{R}=(\mathrm{ALAT} / \mathrm{ULN}) /(\mathrm{ALP} / \mathrm{ULN})[8]$

\begin{tabular}{|c|c|c|c|c|}
\hline & $\begin{array}{l}\text { All patients with } \\
\text { abnormal LFTs } \\
(n=134)\end{array}$ & $\begin{array}{l}\text { Non-severe COVID-19 } \\
(n=104)\end{array}$ & $\begin{array}{l}\text { Severe COVID-19 } \\
(n=30)\end{array}$ & $p$ \\
\hline Age (years) & $51(43-62)$ & $50(40-59)$ & $60(49-75)$ & $<0.0001$ \\
\hline Gender $(\mathrm{M}: \mathrm{F})$ & $69 / 65$ & $54 / 50$ & $15 / 15$ & 1 \\
\hline Symptomatic $(\mathrm{Y} / \mathrm{N})$ & $87 / 47$ & $58 / 46$ & $29 / 1$ & $<0.0001$ \\
\hline Charlson comorbidity score & $1(0-4)$ & $1(0-3)$ & $4(1-7)$ & $<0.0001$ \\
\hline Prior liver disease $(\mathrm{Y} / \mathrm{N})$ & $16 / 118$ & $8 / 96$ & $8 / 22$ & 0.009 \\
\hline \multicolumn{5}{|l|}{ Laboratory values } \\
\hline $\operatorname{ALT}(\mathrm{U} / \mathrm{L})$ & $100(56-151)$ & $106(68-146)$ & $76(43-163)$ & 0.1 \\
\hline AST (U/L) & $65(49-105)$ & $64(48-94)$ & $75(49-156)$ & 0.1 \\
\hline GGT (U/L) & $88(49-130)$ & $96(51-128)$ & $83(42-161)$ & 0.7 \\
\hline $\operatorname{ALP}(\mathrm{U} / \mathrm{L})$ & $80(55-123)$ & $78(56-120)$ & $102(55-152)$ & 0.4 \\
\hline $\begin{array}{l}\text { Type of liver injury } \\
\mathrm{R}^{*}>5 / 2-5 /<2\end{array}$ & $8 / 25 / 84$ & $6 / 22 / 63$ & $2 / 3 / 21$ & 0.4 \\
\hline Duration of LFT elevation (days) & $7(5-10)$ & $7(5-10)$ & $7(4-9)$ & 0.2 \\
\hline Total bilirubin $(\mathrm{mg} / \mathrm{dL})$ & $0.63(0.44-0.98)$ & $0.66(0.43-0.96)$ & $0.54(0.45-1.12)$ & 0.9 \\
\hline Albumin $(\mathrm{g} / \mathrm{dL})$ & $3.2(2.8-3.5)$ & $3.2(2.9-3.5)$ & $2.9(2.7-3.5)$ & 0.1 \\
\hline INR & $1.04(0.96-1.14)$ & $1.04(0.97-1.1)$ & $1.13(0.95-1.2)$ & 0.09 \\
\hline $\mathrm{Hb}(\mathrm{g} / \mathrm{dL})$ & $13.3(11.9-14.5)$ & $13.4(12.4-14.7)$ & $11.5(10.4-14.1)$ & 0.002 \\
\hline WBC $\left(* 10^{-3} \mathrm{~L}\right)$ & $6175(4645-8398)$ & $6185(4646-8080)$ & 5965(4406-9127) & 0.9 \\
\hline Neutrophils $\left(* / 10^{-3} \mathrm{~L}\right)$ & $4005(2620-6000)$ & $3923(2591-5738)$ & $4360(3179-8029)$ & 0.1 \\
\hline Platelets $(* / \mathrm{L})$ & $210(156-274)$ & $218(107-244)$ & $195(162-218)$ & 0.01 \\
\hline $\mathrm{CRP}(\mathrm{mg} / \mathrm{L})$ & $2.3(0.8-7.4)$ & $2.1(0.7-5.9)$ & $4.6(1-22)$ & $\mathbf{0 . 0 2}$ \\
\hline Creatinine (mg/dL) & $0.8(0.6-0.9)$ & $0.8(0.6-0.9)$ & $0.8(0.6-1.5)$ & 0.4 \\
\hline $\mathrm{Na}(\mathrm{mEq} / \mathrm{L})$ & $139(135-141)$ & 139(135-141) & $137(133-142)$ & 0.3 \\
\hline $\mathrm{K}(\mathrm{mEq} / \mathrm{L})$ & $4.3(4-4.7)$ & $4.3(4-4.6)$ & $4.3(4.1-4.8)$ & 0.9 \\
\hline \multicolumn{5}{|l|}{ Treatment and outcome } \\
\hline Acetaminophen $(\mathrm{Y} / \mathrm{N})$ & $56 / 78$ & $42 / 62$ & $14 / 16$ & 0.3 \\
\hline Hydroxychloroquine (Y/N) & $62 / 72$ & $44 / 60$ & $18 / 12$ & 0.06 \\
\hline Lopinavir/ ritonavir $(\mathrm{Y} / \mathrm{N})$ & $85 / 49$ & $74 / 30$ & $11 / 19$ & 0.001 \\
\hline Antibiotics $(\mathrm{Y} / \mathrm{N})$ & $78 / 56$ & $53 / 51$ & $25 / 5$ & 0.001 \\
\hline Hospitalization period (days) & $17(12-24)$ & $18(13-24)$ & $12(6-25)$ & 0.1 \\
\hline Admission to ICU $(\mathrm{Y} / \mathrm{N})$ & $16 / 118$ & $1 / 103$ & $15 / 15$ & $<0.001$ \\
\hline Fatal outcome $(\mathrm{Y} / \mathrm{N})$ & $16 / 118$ & $1 / 103$ & $15 / 15$ & $<0.001$ \\
\hline
\end{tabular}

\section{Liver injury}

$91.8 \%$ of patients had abnormal LFT values on admission, while the rest developed LFT elevation after a median of 3 days. The majority of abnormal LFT values were below 3xULN, $72 \%$ of patients had a cholestatic pattern of liver injury, and $7 \%$ had a hepatocellular pattern. Patients who received lopinavir/ritonavir were more likely to have increased ALAT levels $(p<0.0001)$ during admission, while those on antibiotics had a higher mean alkaline phosphatase level $(p=0.006)$.

Sixteen patients in our cohort ( 8 of them women; mean age: $61.8 \pm 3.8$ years) had preexisting chronic liver disease: 11 - chronic viral hepatitis and 5 - cirrhosis (3 with alcoholic cirrhosis, 1 with $\mathrm{HBV}, 1$ with mixed alcoholic + HBV). Thirteen patients were symptomatic, $8 / 16$ fulfilled the criteria for severe infection while the rest had mild/moderate forms of COVID-19. Eleven received acetaminophen, 12 were treated with hydroxychloroquine, 3 with lopinavir/ ritonavir, and 12 were treated with antibiotics. They were hospitalized for a mean duration of $16.7 \pm 3$ days, and $7 / 16$ patients were admitted to the ICU and died after $5 \pm 2$ days. Four out of the five patients with cirrhosis had severe COVID-19, and 3 of them died. A comparison between patients with and without prior liver disease is presented in Table 2. Patients with previously 
diagnosed chronic liver disease were more likely to be older, have more severe forms of COVID19, and a higher Charlson comorbidity index. They were also more likely to be admitted to the
ICU and reach a fatal outcome. From a biological standpoint, they had higher CRP, lower platelets, hemoglobin, and, surprisingly, lower ALAT levels.

Table 2.

Comparison between patients with COVID-19 with and without pre-existing liver disease

\begin{tabular}{|c|c|c|c|}
\hline & $\begin{array}{l}\text { Chronic liver disease } \\
(n=16)\end{array}$ & $\begin{array}{l}\text { No chronic liver disease } \\
(\mathrm{n}=118)\end{array}$ & $p$ \\
\hline Age (years) & $59(51-76)$ & $50(41-60)$ & 0.008 \\
\hline Gender $(\mathrm{M}: \mathrm{F})$ & $8 / 8$ & $61 / 57$ & 0.5 \\
\hline Symptomatic (Y/N) & $13 / 3$ & $74 / 44$ & 0.1 \\
\hline COVID-19 severity (non-severe/severe) & $8 / 18$ & $96 / 22$ & 0.009 \\
\hline Charlson comorbidity score & $6(3-9)$ & $1(0-3)$ & $<0.0001$ \\
\hline ALT (U/L) & $37(14-145)$ & $104(66-152)$ & 0.002 \\
\hline AST (U/L) & $68(27-177)$ & $65(49-99)$ & 0.8 \\
\hline GGT (U/L) & $82(42-120)$ & $90(50-134)$ & 0.7 \\
\hline Alkaline phosphatase (U/L) & $96(77-144)$ & $76(55-120)$ & 0.06 \\
\hline Duration of LFT elevation (days) & $12(3-25)$ & $7(5-10)$ & 0.1 \\
\hline Total bilirubin $(\mathrm{mg} / \mathrm{dL})$ & $0.7(0.5-1.8)$ & $0.6(0.4-0.8)$ & 0.1 \\
\hline Albumin $(\mathrm{g} / \mathrm{dL})$ & $3.1(2.2-3.7)$ & $3.2(2.9-3.5)$ & 0.6 \\
\hline INR & $1.1(1-1.6)$ & $1(0.9-1.1)$ & 0.006 \\
\hline $\mathrm{Hb}(\mathrm{g} / \mathrm{dL})$ & $11.2(9.4-13)$ & $13.5(12.2-14.7)$ & $<0.0001$ \\
\hline WBC $\left(* 10^{-3} \mathrm{~L}\right)$ & $6330(5187-10560)$ & $6175(4565-8212)$ & 0.3 \\
\hline Neutrophils $\left(* 10^{-3} \mathrm{~L}\right)$ & $5006(3549-7562)$ & $3923(2602-5942)$ & 0.08 \\
\hline Platelets (*/L) & $120(82-254)$ & $215(161-274)$ & 0.008 \\
\hline $\mathrm{CRP}(\mathrm{mg} / \mathrm{L})$ & $28(6.2-68.4)$ & $1.8(0.7-5.5)$ & $<0.0001$ \\
\hline Creatinine (mg/dL) & $0.8(0.7-1.7)$ & $0.8(0.6-0.9)$ & 0.1 \\
\hline $\mathrm{Na}(\mathrm{mEq} / \mathrm{L})$ & $137(131-141)$ & $139(135-141)$ & 0.3 \\
\hline $\mathrm{K}(\mathrm{mEq} / \mathrm{L})$ & $4.3(3.8-4.4)$ & $4.3(4-4.7)$ & 0.3 \\
\hline Acetaminophen $(\mathrm{Y} / \mathrm{N})$ & $11 / 5$ & $45 / 73$ & $\mathbf{0 . 0 2}$ \\
\hline Hydroxychloroquine (Y/N) & $12 / 4$ & $50 / 68$ & 0.01 \\
\hline Lopinavir/ ritonavir $(\mathrm{Y} / \mathrm{N})$ & $3 / 13$ & $82 / 36$ & $<0.0001$ \\
\hline Antibiotics $(\mathrm{Y} / \mathrm{N})$ & $12 / 4$ & $66 / 52$ & 0.1 \\
\hline Hospitalization period (days) & $17(4-25)$ & $17(13-24)$ & 0.4 \\
\hline Admission to ICU $(\mathrm{Y} / \mathrm{N})$ & $7 / 9$ & $9 / 109$ & 0.001 \\
\hline Fatal outcome $(\mathrm{Y} / \mathrm{N})$ & $7 / 9$ & $9 / 109$ & 0.001 \\
\hline
\end{tabular}

\section{Histopathology correlations}

In order to further investigate the role of SARS-CoV-2 infection in liver injury, we evaluated liver samples from autopsies performed on two patients who died four days after admission: a 51 years-old man, and a 53 years-old woman, with no prior liver disease, both with type II diabetes. They had severe inflammatory syndrome and ALAT and ASAT levels 3xULN on admission. Microscopic examination of the liver specimens showed similar, non-specific mild sinusoidal dilatation, without vascular lesions, mild-moderate macro- and microvacuolar steatosis predominantly in acinar zone 3 without hepatocyte necrosis, or lobular lymphocytic infiltration and with minimal portal activity (Figure 1). These injuries are more consistent with drug-induced lesions rather than direct viral effects.

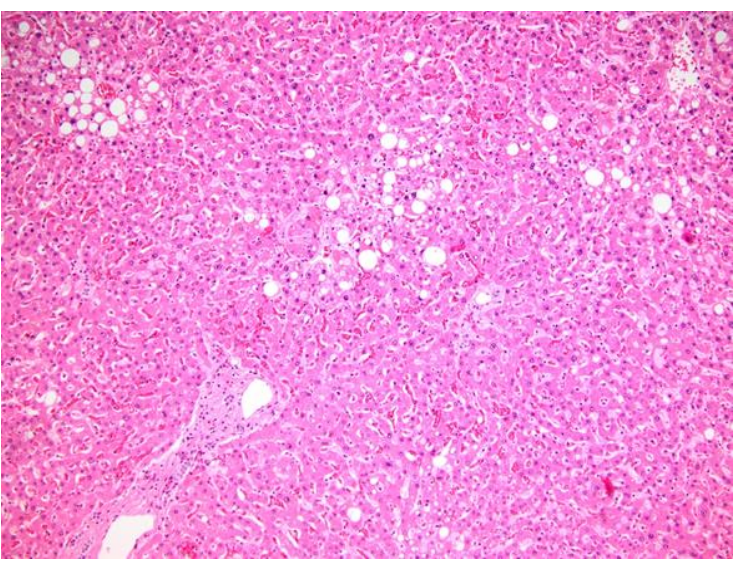

Figure 1. Liver specimen (hematoxylin-eosin, 100x) from a 51-year old man showing moderate sinusoidal dilatation and mild macro- and micro-vacuolar steatosis compatible with drug-induced liver injury. The patient had a history of diabetes mellitus and received treatment with lopinavir/ritonavir, hydroxychloroquine, enoxaparin, and tocilizumab for severe COVID-19. 


\section{Outcomes}

Sixteen patients died during the study period. On univariate analysis, they were more likely to have severe COVID-19 $(p<0.001)$, prior liver disease $(p=0.001)$, lower hemoglobin $(p<0.001)$ and platelet count $(p=0.02)$, a profound inflammatory syndrome reflected by higher CRP levels $(\mathrm{p}=0.002)$, neutrophils and SIRS on admission, and a higher Charlson comorbidity index $(p<0.001)$. We conducted a multivariable analysis using logistic regression and adjusting for age, gender, pre-existing

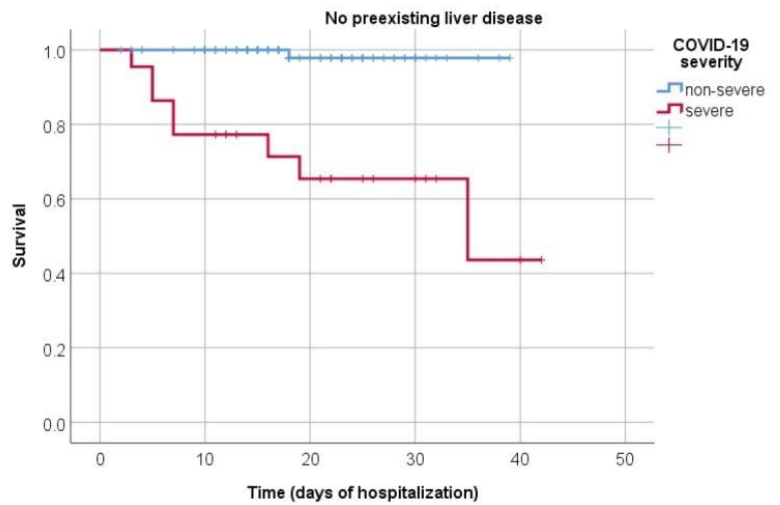

liver disease, Charlson comorbidity index, and CRP levels and found that COVID-19 severity was the only risk factor for death during admission (OR 69.9, 95\%CI 6.4-761.4). A survival analysis adjusted for chronic liver disease is presented in Figure 2. Patients with pre-existing liver disease and severe COVID-19 presented with a lower survival rate than patients without any pre-existing liver disease. Admission period was longer in patients with severe COVID-19 without pre-existing liver disease, and the survival rate was lower than in patients with non-severe COVID-19.

Figure 2. Kaplan-Meier analysis of survival according to the severity of COVID-19 adjusted for the presence of chronic liver disease shows decreased survival in patients with severe COVID-19 $\left(\chi^{2}(1)=35.496, p<0.0001\right)$.

\section{DISCUSSIONS}

This study found that liver injury is a common finding in SARS-CoV-2 infection, of limited clinical significance in patients without pre-existing liver disease. Furthermore, liver injury was not an independent risk factor for the outcome of COVID-19, even in patients with chronic liver disease.

Our results fall in line with other reports that showed elevation of liver function tests as a frequent occurrence in patients without previously diagnosed liver disease. These biological anomalies are uncertain but probably minimal clinical significance and, for the most part, likely attributable to drug-induced liver damage. We noted that patients without prior liver disease, who also were more likely to be treated with lopinavir/ritonavir, also had increased ALT levels. A hepatocellular pattern of liver injury is frequently encountered during treatment with lopinavir/ritonavir and may exacerbate chronic liver disease due to $\mathrm{HCV}$ or $\mathrm{HCV}$ infection $[8,9]$. The World Health Organization discontinued the lopinavir/ritonavir treatment arm of the

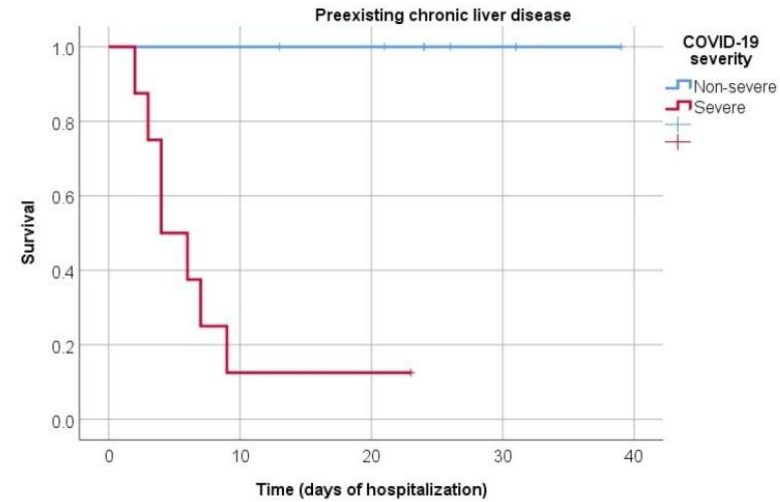

international Solidarity trial, probably due to concerning safety signals $[10,11]$. Pre-existing undiagnosed chronic liver disease is a confounder by design in all similar reports of liver injury in COVID-19 patients, and drug-induced liver injury lacks pathognomonic features. While the liver specimens evaluated in our cohort showed signs of drug-induced liver injury, it is impossible to ascribe causality, especially since multiple potential hepatotoxic drugs were introduced simultaneously in some of these patients.

In a large cohort of patients, Marjot et al. [12] highlighted the risk factors in patients with pre-existing liver disease and demonstrated that baseline stage of liver disease and alcohol-related liver disease were independent risk factors for death from COVID-19, as the mortality was higher in patients with end-stage liver disease.

In their study regarding the implications of liver injury in risk-stratification and management of patients with COVID-19, Shao et al. [13] have found that the patients who developed liver injury during hospitalization had higher mortality and ICU admission rates than those without liver injury. We have also observed that patients with liver injury had 
a significantly prolonged hospital stay, making them susceptible to possible post-admission complications. Sikkema et al. [14] have also concluded that COVID-19 related liver injury at the time of diagnosis of COVID-19 does not seem to be associated with a more severe course of the disease in our hospital. In a cross-sectional, follow-up study, An et al. [15] concluded that abnormal liver function indicates worse recovery of COVID-19 patients and that the changes in liver function should be emphasized during long-term follow-up of COVID19 patients after hospital discharge. The emphasis on appropriate intervention and guidance for hepatologists for liver function repair should be established in our cohort of patients, and a follow-up study is therefore imposed.

The World Gastroenterology Organization (WGO) has published a recent guidance paper [16] for the care of patients with COVID-19 and liver disease and presented a step-wise approach in COVID-19 patients suspected to have a hepatobiliary disease. Although our cohort of patients with pre-existing liver disease is limited, the practical aspects of caring for patients during COVID-19 should be imposed in the general practice of every hepatologist. We consider that the experience of the gastroenterologists from these dedicated COVID-19 units involving the treatment in patients with pre-existing liver disease was significantly improved regarding the care of patients during COVID-19 pandemic and their strict follow-up.
There are some limitations to our study. Due to the retrospective nature of our research and the lack of further testing (such as viral serology, detailed history of alcohol consumption, transient elastography), we could not exclude undiagnosed pre-existing liver disease as the cause for LFT elevation, especially since our cohort included older patients, with risk factors for metabolic syndrome. There is still no definitive evidence of a direct viral effect on the liver, and the primary pathophysiological mechanisms involved in liver injury seen in patients with COVID-19 probably include altered immune response and cytokine production as well as drug-induced damage $[17,18]$. Consequently, great care must be exercised in choosing and monitoring "antiviral medication" in this group.

\section{CONCLUSIONS}

Our analysis of patients admitted for COVID-19 revealed that liver injury is common and mild. While patients with pre-existing liver disease are at risk for a negative outcome, the severity of the COVID-19 was the only independent predictor of death in this cohort of patients. We recommend careful monitoring and follow-up of liver function in this frail population due to the risk for decompensation represented by aggressive viral infection and polymedication.

Introducere. Pacienții cu COVID-19 prezintă frecvent modificări ale funcției hepatice fără o etiologie certă. Scopul studiului a fost de a investiga factorii și caracteristicile pacienților cu infecție SARS-CoV-2 ce au prezentat afectare hepatică la internare.

Metode. A fost realizat un studiu observațional retrospectiv din două spitale COVID din România. Au fost analizate datele clinice și de laborator, precum și medicația administrată ce s-au asociat cu un prognostic prost. Au fost incluși în studiu pacienți cu COVID-19 confirmat și cu modificări ale testelor hepatice.

Rezultate. Din 1207 pacienți 134 (11\%) au indeplinit criteriile de includere. Majoritatea pacienților au prezentat un sindrom colestatic. Pacienții cu terapie lopinavir/ritonavir au avut niveluri ALAT mai mari ( $p<0,0001)$. 16 pacienți aveau afectare hepatică anterioară și aceștia au avut prognostic mai prost ( $p<0,001)$, insă în analiza multivariată numai severitatea COVID-19 a fost predictor pentru deces (OR 69,9; 95\% CI 6,4-761,4).

Concluzii. Afectarea hepatică ușoară este relativ frecventă în COVID-19 și poate fi influențată de medicație. Pacienții cu afectare cronică hepatică sunt la risc de a dezvolta forme mai grave, însă predictor pentru deces a fost numai severitatea infecției cu SARS-CoV-2. 
Correspondence to: Adina Roman, M.D, Gastroenterology Department, Mureș County Clinical Hospital, Romania, 1 Gheorghe Marinescu Street, Targu Mures, Romania E-mail: adina.roman91@gmail.com, Phone: +40752934465

Conflict of interest disclosure: The authors declare there is no conflict of interest

Acknowledgments: We would like to acknowledge the dedication and support of the entire personnel involved in the care of patients suffering from COVID-19 at Mureș County Clinical Hospital and Colentina Clinical Hospital.

Authors' contribution: Voiosu A and Roman A share first authorship and provided statistical analysis, reviewed the literature, participated in the writing of the article, reviewed and approved the final draft. Pop $\mathrm{R}$ and Voiosu $\mathrm{T}$ collected the data, interpreted the results, participated in the writing, and reviewed and approved the final draft. Popp $\mathrm{C}$ and Zurac $\mathrm{C}$ participated in the writing of the paper, reviewed and approved the final draft. Dobru D, Boeriu A, and Mateescu B designed the study, participated in the writing of the paper, reviewed, revised, and approved the final draft. Dobru D and Mateescu B share senior authorship.

\section{REFERENCES}

1. CICHOŻ-LACH H., MICHALAK A. Liver injury in the era of COVID-19. World journal of gastroenterology 2021;27(5): 377.

2. DONG ZY, et al. The prevalence of gastrointestinal symptoms, abnormal liver function, digestive system disease and liver disease in COVID-19 infection: a systematic review and meta-analysis. Journal of Clinical Gastroenterology 2021; 55(1): 67.

3. KUNUTSOR SK., LAUKKANEN JA. Markers of liver injury and clinical outcomes in COVID-19 patients: a systematic review and meta-analysis. Journal of Infection 2021; 82(1): 159-198.

4. NARDO AD, et al. Pathophysiological mechanisms of liver injury in COVID-19. Liver International 2021; 41(1): 20-32.

5. JOTHIMANI D, VENUGOPAL R, ABEDIN MF, KALIAMOORTHY I, RELA M. COVID-19 and Liver [published online ahead of print, 2020 Jun 15]. J Hepatol. 2020; S0168-8278(20)30377-9.

6. https://www.covid-hep.net/

7. ALQAHTANI SA, SCHATTENBERG JM. Liver injury in COVID-19: The current evidence. United European Gastroenterol J. 2020;8(5):509-519.

8. European Association for the Study of the Liver. Electronic address: easloffice@easloffice.eu; Clinical Practice Guideline Panel: Chair; Panel members; EASL Governing Board representative: EASL Clinical Practice Guidelines: Drug-induced liver injury. J Hepatol. 2019 Jun;70(6):1222-1261

9. GARRIDO I, LIBERAL R, MACEDO G. Review article: COVID-19 and liver disease-what we know on 1st May 2020. Aliment Pharmacol Ther. 2020;52(2):267-275. doi:10.1111/apt.15813

10. https://www.ncbi.nlm.nih.gov/books/NBK547961/ [accessed 25 July 2020]

11. https://www.who.int/news-room/detail/04-07-2020-who-discontinues-hydroxychloroquine-and-lopinavir-ritonavir-treatmentarms-for-covid-19 [accessed 25 July 2020]

12. MARJOT, T, et al. Outcomes following SARS-CoV-2 infection in patients with chronic liver disease: An international registry study. J Hep 2021; 74(3): 567-577

13. SHAO, J., et al. Implications of liver injury in risk-stratification and management of patients with COVID-19. Hepatology international (2021): 1-11.

14. SIKKEMA, B. J., NICOLAAS, JS., VAN WIJNGAARDEN P. No association between COVID-19 related liver injury and the course of disease: a retrospective study. Scandinavian Journal of Gastroenterology 2021; 56(1): 68-71.

15. YA-WEN A., et al. Liver function recovery of COVID-19 patients after discharge, a follow-up study. International journal of medical sciences 2021; 18 (1): 176.

16. HAMID S., et al. WGO Guidance for the Care of Patients with COVID-19 and Liver Disease. Journal of Clinical Gastroenterology 2021; 55 (1): 1.

17. ZHANG C, SHI L, WANG FS. Liver injury in COVID-19: management and challenges. Lancet Gastroenterol Hepatol. 2020;5(5):428-430.

18. https://www.who.int/publications/i/item/clinical-management-of-covid-19

Received $24^{\text {th }}$ May 2021 